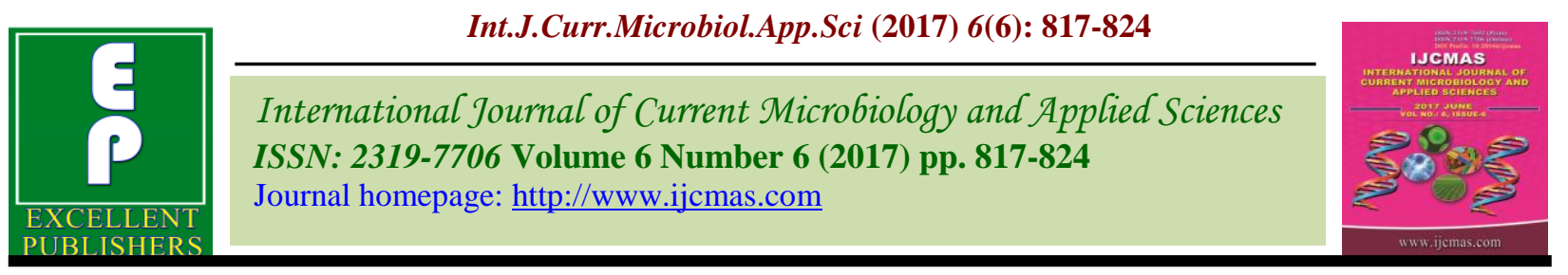

Original Research Article

https://doi.org/10.20546/ijcmas.2017.606.096

\title{
Development of Perception Test for Human-Wildlife Conflict
}

\author{
K. Senthilkumar ${ }^{1 *}$, P. Mathialagan ${ }^{2}$, V.E. Sabarathnam ${ }^{3}$ and C. Manivannan ${ }^{4}$ \\ ${ }^{1}$ Department of Wildlife Science, Madras Veterinary College, Tamil Nadu Veterinary and \\ Animal Sciences University, Chennai, Tamil Nadu, India \\ ${ }^{2}$ TANUVAS, Chennai-51, India \\ ${ }^{3}$ Department of Veterinary and Animal Husbandry Extension Education, \\ Madras Veterinary College, Chennai-7, India \\ ${ }^{4}$ University Publication division, TANUVAS, Chennai-51, India \\ *Corresponding author
}

\begin{tabular}{|c|c|}
\hline & A B S T R A C T \\
\hline & \multirow{5}{*}{$\begin{array}{l}\text { The present study was conducted in two districts namely, Erode and } \\
\text { Coimbatore districts of Tamil Nadu State with sample size of } 60 \text { farmers to } \\
\text { develop a perception test for Human-wildlife conflict (HWC). Eight } \\
\text { components of Human-wildlife conflict perception of affected farmers, } \\
\text { Socio-cultural Impact, economic impact, reasons for HWC, responsibility } \\
\text { in reducing HWC, efforts of villagers after HWC, eco centrisim, } \\
\text { antropocentrism and environmental apathy were selected based on } \\
\text { relevancy weightage and scale value. The perception test was developed by } \\
\text { following the standard procedure given by Edwards (1969) to frame } \\
\text { statements, farmer's response on items, item analysis, validity and } \\
\text { reliability. A total number of } 10 \text { items which had p value of } 21 \text { to } 75 \text {, } \\
\text { discrimination index of } 0.21 \text { to } 0.75 \text { and significant rp bis were selected for } \\
\text { the final perception test. }\end{array}$} \\
\hline $\begin{array}{l}\text { Ke y w o r d s } \\
\text { Perception, } \\
\text { Environment, } \\
\text { Development } \\
\text { and Conflict. }\end{array}$ & \\
\hline Article Info & \\
\hline $\begin{array}{l}\text { Accepted: } \\
\text { 14 May } 2017 \\
\text { Available Online: } \\
\text { 10 June } 2017\end{array}$ & \\
\hline & \\
\hline
\end{tabular}

\section{Introduction}

Human-wildlife conflict (HWC) is an emerging problem among the people at the buffer zones of protected areas. The commonly occurring conflicts include cropraiding events, property damage and human causalities, among other forms (Dickman, 2010). The common wildlife encountering with humans are elephant, wild boar, and primates. Overabundant wild boar and feral pigs are associated with disease transmission and negative impacts on agriculture, native
Wildlife and, particularly where they occur around urban areas, public safety (Quy et al., 2014). Crop raiding was found to be predominantly directed at maize and perceived at least to be carried out solely by primates (Mc Guinness and Taylor, 2014). The peoples are managing the HWC in different ways, which include solar/wire messed fencing, frightening, and trenching. The need of the hour is community-based management by placing fences around risk- 
prone villages and managing abandoned farmlands in a village. The costs of HWC included decreased food security, changes to workload, decreased physical and psychological wellbeing, economic hardship, and at times an increase in illegal or dangerous activities (Ogra, 2008).

Sometimes people lost their patience and tried to kill the wild animals as a final resort to get rid of HWC. Some authors have studied the people's perception towards human-wildlife conflict. Thompson and Barton (1994) developed a scale to study the eco centric and anthropocentric attitudes towards environment. Hence a psychological test was developed to study the people's perception about HWC because perception is a psychological object and procedures are available to develop standard psychological tests.

\section{Materials and Methods}

Based on the review of literature and discussion with experts, items for the test were collected. The statements were edited and revised based on the suggestion of judges. A total number of 56 items (Annexure- I) was administered to 60 farmers of HWC area in Erode and Coimbatore districts of Tamil Nadu, India. An interview schedule was prepared with these 56 items and the response was personally collected from the farmers.

\section{Scoring of responses}

The responses obtained from the 60 farmers were subject to item analysis. To analyse 56 items, each one of the 60 respondents to whom the test was administered, was scored on the basis of the score allotted. i.e. ' 1 ' for correct response and ' 0 ' for incorrect responses for each item. Thus, score could range from 0 to 56 .
These 60 respondents were then divided into three groups i.e. 20, 20, 20 for the purpose of analysis of 'discrimination index', the middle group was eliminated as suggested by Sabarathnam (1987). The scores of these groups ranged as follows:

$\mathrm{G} 1=49$ to 38

$\mathrm{G} 2=37$ to 35

$\mathrm{G} 3=34$ to 25

\section{Results and Discussion}

\section{Selection of items for final test}

The selection of items for the perception test of Human-wildlife conflict was done based on the following criteria (Table 1).

\section{Item difficulty index}

The item-difficulty index was worked out as the percentage of the respondents answering an item correctly. The assumption in this item statistic of difficulty was that the difficulty is linearly related to the level of perception of the respondent about human-wildlife conflict. For selection of items based on difficulty indices, normal curve was taken. That is the items with difficulty indices ( $\mathrm{p}$ value) ranging from 0.21 to 0.75 were considered for final selection as followed by Parishad (1981).

To rule out answers, which are likely to be a mere guesswork, correcting difficulty indices for chance success were worked as suggested by Garret (2011) using the following formula

$\mathrm{Pc}_{\mathrm{c}}=\frac{R-\frac{w}{(k-1)}}{(\mathrm{N}-\mathrm{HR})}$

Where,

Pc - The per cent who actually know the right answer 
$\mathrm{R}$-The number who get right answer

$\mathrm{W}$-The number who get wrong answer

$\mathrm{N}$-The number of examinees in the sample

HR-The number of examinees who do not

reach the item (Hence, do not try it)

$\mathrm{K}$-The number of options or choices

\section{Item discrimination index}

The next criterion for selecting the items to incorporate in the final scale/test was item discrimination index, which is symbolized by $\Sigma 1 / 3$. The method suggested by Sabarathnam (1987) was adopted to find out the item discrimination index. The discrimination indices for all items were calculated using the following formula:

$\Sigma 1 / 3=\frac{G 1-G 3}{\mathrm{~N} / 3}$
Where,

G1 - Frequency of correct answers for an item in the group 1

G3 - Frequency of correct answers for item in the group 3.

$\mathrm{N} \quad$ - Total number of respondents in the sample selected for item analysis i.e., 60.

The item discrimination index was found out for all the items and those with discrimination index between 0.21 and 0.75 were selected for the final test. Since the discrimination index varies between 0 and 1 , it was considered necessary to select item with at least 0.21 discrimination indexes to be the lowest discrimination index point in order to have a wider continuum of discrimination of the items.

Table.1 Perception of villagers on Human-Wildlife Conflict (HWC)

\begin{tabular}{|c|c|c|c|}
\hline S. No. & Statements & $\begin{array}{c}\text { Agree } \\
(\text { Score - 1) }\end{array}$ & $\begin{array}{c}\text { Disagree } \\
(\text { Score }-0)\end{array}$ \\
\hline I. & \multicolumn{3}{|l|}{ Economic Impact } \\
\hline 1. & HWC results in less damage to crops & & \\
\hline 2. & $\begin{array}{l}\text { Sudden attack of wild animals on public property like ration shop, } \\
\text { temporarily stored harvested sugarcane and paddy bags result in heavy } \\
\text { loss }\end{array}$ & & \\
\hline II. & \multicolumn{3}{|l|}{ Reasons for HWC } \\
\hline 3. & $\begin{array}{l}\text { Even animal feed inadequacy in a forest area lead wild animals remain } \\
\text { in the same area instead of moving to the buffer zones of forest }\end{array}$ & & \\
\hline III. & \multicolumn{3}{|l|}{ Efforts of the villagers after $\mathrm{HWC}$} \\
\hline 4. & $\begin{array}{l}\text { Pressurizing the forest officials to know HWC in their area, but not } \\
\text { informing about HWC }\end{array}$ & & \\
\hline 5. & Self-effort for protection against HWC & & \\
\hline IV. & \multicolumn{3}{|l|}{ Eco-centrism } \\
\hline 6. & $\begin{array}{l}\text { One cannot enjoy spending time in natural settings for the sake of being } \\
\text { out in nature }\end{array}$ & & \\
\hline 7. & I need time in nature to be happy & & \\
\hline V. & \multicolumn{3}{|l|}{ Anthropocentrism } \\
\hline 8. & Nature is important as it contributes for pleasure and human welfare & & \\
\hline 9. & Main reason to conserve is to maintain high standard of living & & \\
\hline VI. & \multicolumn{3}{|l|}{ Environmental apathy } \\
\hline 10. & It is too much for anybody to get concerned about environmental issues & & \\
\hline
\end{tabular}


Table.2 Selection of test items of the human-wildlife conflict perception test

\begin{tabular}{|c|c|c|c|c|c|c|c|}
\hline $\begin{array}{l}\text { Sl. } \\
\text { No. }\end{array}$ & $\begin{array}{l}\text { Item } \\
\text { No. }\end{array}$ & Item-Description & $\begin{array}{c}\text { Key } \\
\text { A/DA }^{1}\end{array}$ & $\begin{array}{l}\text { Difficulty } \\
\text { Index (p) }\end{array}$ & $\begin{array}{c}\text { Difficulty } \\
\text { Index for } \\
\text { chance } \\
\text { success (p) }\end{array}$ & $\begin{array}{c}\text { Discrimin } \\
\text { ation } \\
\text { Index } \\
\text { E 1/3 }\end{array}$ & $\begin{array}{r}\text { Point } \\
\text { biseria } \\
\text { rpbis }\end{array}$ \\
\hline 1 & 11 & HWC results in less damage to crops & DA & 0.73 & 0.47 & 0.25 & $0.3^{*}$ \\
\hline 2 & 15 & $\begin{array}{l}\text { Sudden attack of wild animals on public property like ration shop, temporarily } \\
\text { stored harvested sugarcane and paddy bags result in heavy loss. }\end{array}$ & A & 0.73 & 0.7 & 0.25 & $0.34 *$ \\
\hline 3 & 16 & Large scale deforestation forces wild animals do move out and cause HWC. & A & 0.45 & 0.36 & 0.3 & $0.15^{\mathrm{NS}}$ \\
\hline 4 & 19 & $\begin{array}{l}\text { Even animal feed inadequacy in a forest area lead wild animals remain in the } \\
\text { same area instead of moving to the buffer zones of forest }\end{array}$ & DA & 0.50 & 0.49 & 0.35 & $0.33 *$ \\
\hline 5 & 29 & $\begin{array}{l}\text { Pressurizing the forest officials to know HWC in their area, but not informing } \\
\text { about HWC. }\end{array}$ & DA & 0.73 & 0.46 & 0.25 & $0.55^{* *}$ \\
\hline 6 & 31 & Self-effort for protection against HWC & $\mathrm{A}$ & 0.5 & 0.49 & 0.35 & $0.33 * *$ \\
\hline 7 & 33 & $\begin{array}{l}\text { One cannot enjoy spending time in natural settings for the sake of being out in } \\
\text { nature. }\end{array}$ & DA & 0.8 & 0.6 & 0.25 & $0.36^{*}$ \\
\hline 8 & 36 & I need time in nature to be happy & A & 0.8 & 0.6 & 0.25 & $0.38 *$ \\
\hline 9 & 48 & Nature is important as it contributes for pleasure and human welfare & A & 0.41 & 0.4 & 0.4 & $0.43^{*}$ \\
\hline 10 & 50 & Main reason to conserve is to maintain high standard of living & A & 0.86 & 0.73 & 0.4 & $0.63 *$ \\
\hline 11 & 53 & It is too much for anybody to get concerned about environmental issues & DA & 0.52 & 0.5 & 0.45 & $0.48 *$ \\
\hline
\end{tabular}

1- A-Agree; DA-Disagree

*- significant at rpbis $=0.237$ at 5 percent level

**-significant at rpbis $=0.354$ at 1 percent level

NS- Not significant and hence not selected for final perception test (Item 16) 
Table.3 Statements for studying the perception of farmers towards Human-Wildlife Conflict (HWC)

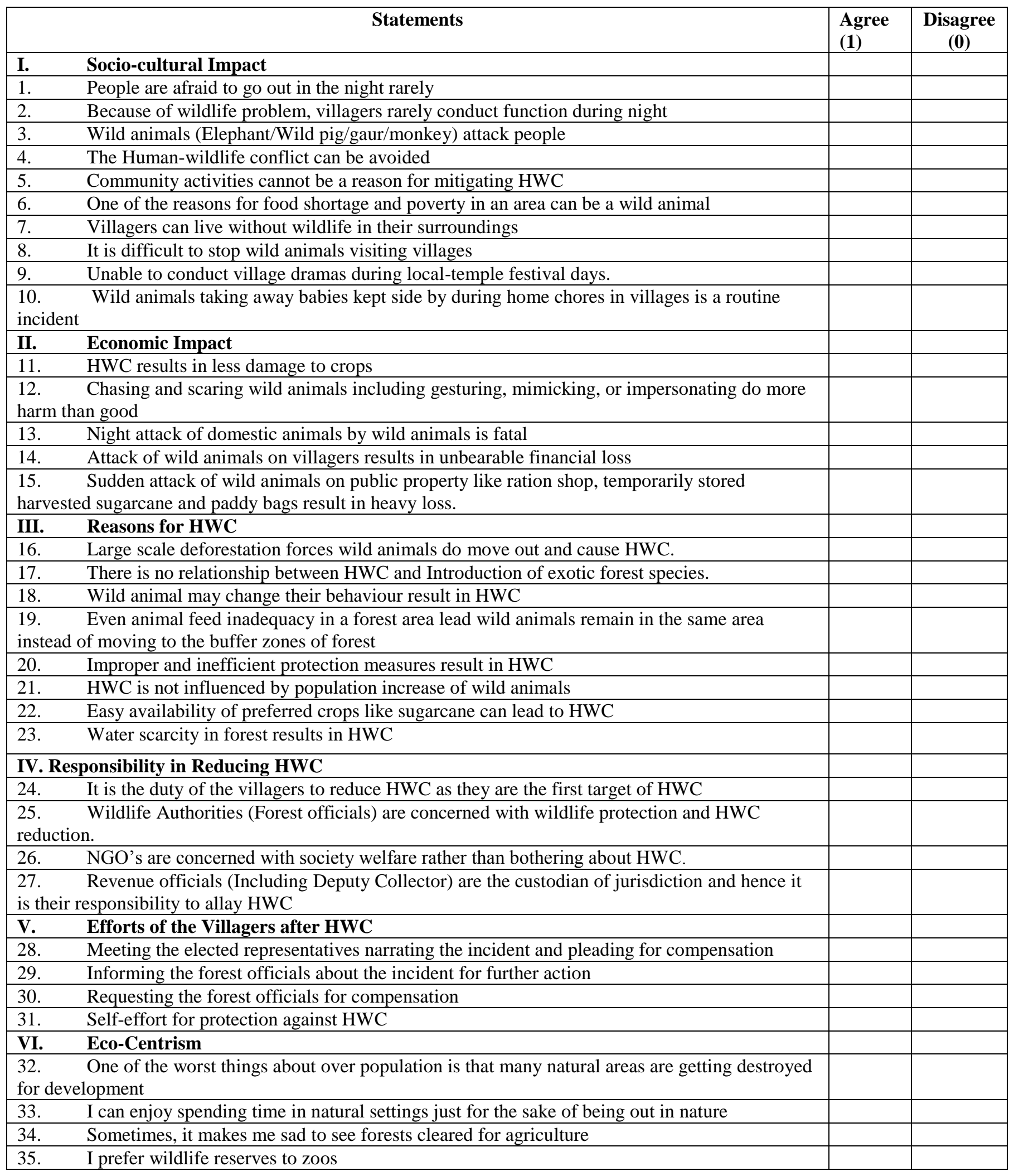




\begin{tabular}{|c|c|c|}
\hline 36. & I need time in nature to be happy & \\
\hline 37. & Sometimes when I am unhappy I find comfort in nature & \\
\hline 38. & It makes me sad to see natural environments destroyed & \\
\hline 39. & Being out in nature is a great stress reducer for me & \\
\hline 40. & One of the most important reasons to conserve is to preserve wild areas & \\
\hline 41. & Sometimes, animals seem almost human to me & \\
\hline VII. & Anthropocentrism & \\
\hline $\begin{array}{l}42 . \\
\text { medici }\end{array}$ & $\begin{array}{l}\text { The worst thing about the loss of the rain forest is that it will restrict the development of new } \\
\text { es }\end{array}$ & \\
\hline 43. & The best thing about camping is that it is a cheap vacation & \\
\hline $\begin{array}{l}44 . \\
\text { for fut }\end{array}$ & $\begin{array}{l}\text { The thing that concerns me most about deforestation is that there will not be enough lumber } \\
\text { e generations }\end{array}$ & \\
\hline $\begin{array}{l}45 . \\
\text { to enjo }\end{array}$ & $\begin{array}{l}\text { One of the most important reasons to keep lakes and rivers clean is so that people have a place } \\
\text { water sports }\end{array}$ & \\
\hline 46. & The most important reason for conservation is human survival & \\
\hline 47. & One of the best things about recycling is that it saves money & \\
\hline 48. & Nature is important because of what it can contribute to the pleasure and welfare of humans & \\
\hline 49. & We need to preserve resources to maintain a high quality of life & \\
\hline 50. & One of the most important reasons to conserve is to ensure a continued high standard of living & \\
\hline 51. & Continued land development is a good idea as long as a high quality of life can be preserved & \\
\hline VIII. & Environmental Apathy & \\
\hline 52. & It seems to me that most conservationists are pessimistic and somewhat paranoid. & \\
\hline 53. & I find it hard to get too concerned about environmental issues & \\
\hline 54. & I don't care about environmental problems & \\
\hline 55. & I'm opposed to programs to preserve wilderness, reduce pollution and conserve resources & \\
\hline 56. & Too much emphasis has been placed on conservation & \\
\hline
\end{tabular}

\section{Item Validity Index}

To validate the test, point-biserial ( $\mathrm{rp}$ bis) was estimated. Point-biserial correlation (rp bis) is the test of item validation in which the criterion of validity is considered to be internally consistent. That is, the relationship of total score to be a dichotomized response to any given item. Since the items were scored simply as ' 1 ' if correct and ' 0 ' if incorrect the assumption of normality in the distribution of right-wrong responses was considered as unwarranted, by Garrett (2011). In such cases, he considers point-biserial ' $r$ ' rather than biserial ' $r$ ' as appropriate. Point biserial $r$ assumes that the variable which has been classified into two categories can be thought of as concentrated at two distinct points along a graduated scale or continuum. The formula for the point biserial ' $r$ ' is:

rp bis $=\frac{M p-M q}{\text { S. D }} \times \mathrm{PQ}$

Where,

rp bis - Point biserial correlation coefficient

Mp - Mean score on continuous variable for successful group on dichotomous variable

Mq - Mean score on continuous variable for unsuccessful group on dichotomous variable 
S.D. - Standard deviation of the test score on continuous variable

$\mathrm{P} \quad$ - The proportion of the group answering a test item correctly

Q - Proportion of the group answering a test item wrongly

Point biserial correlation was worked out for those items, which had discrimination index between 0.21 and 0.75 . All the point biserial $r$ values were found out with the aid of the table 51 of Garrett (2011) with $\mathrm{n}-2=58$ degrees of freedom where $\mathrm{n}$ was the number of respondents. The $\mathrm{r}$ value for $58(60-2)$ d.f. as per table at 5 per cent level is 0.237 and 1 per cent level is 0.354 . Hence all the items having point bilateral $\mathrm{r}$ of 0.237 and above were selected for inclusion in the final test of perception of human-wildlife conflict.

\section{The process of elimination of statements}

The $\mathrm{p}$ value i.e., item difficulty index was worked out for all 56 items. Those items which got $p$ value other than the range of 21 to 75 were dropped from further analysis. The item discrimination index was worked out for the statements having $p$ value of 21 to 75 . The items which showed item discrimination other than the range of 0.21 to 0.75 were dropped from further analysis. In this process, only 11 statements were eligible for the point biserial correlation analysis.

\section{Final selection of statements}

Out of eleven statements subject to point biserial correlation analysis, 6 statements were significant at 0.01 level, 2 statements were significant at 0.05 level and one statement was not significant. Finally 10 items which had $\mathrm{p}$ value of 21 to 75 discrimination index of 0.21 to 0.75 and significant rp bis were selected for the final perception test. The item which was not significant $r p$ bis analysis was dropped. The $p$ value, discrimination index and rp bis value of these 10 statements are shown in table 3 .

Scoring technique for perception test on Human-Wildlife Conflict

The tool/test consisting of 10 statements was applied to the respondent to study their perception on Human-wildlife conflict (Table 2). They were asked to indicate their opinion/perception about the items freely. A score of 'one' was given to the correct response and 'zero' for incorrect response with regard to conservation.

The reliability and validity of the test indicated the precision and consistency of the results. Therefore, this test can be used by all persons and organisations to observe the perception of the farmers towards HWC in any area with suitable modification.

\section{References}

Dickman, A.J. 2010. Complexities of conflict: The importance of considering social factors for effectively resolving humanwildlife conflict. Animal Conserv., 13: 1-9.

Edwards, A.L. 1969. Statistical Analysis. Holt Rinehart N.Y. Winston: 1-82.

Mc Guinness, S. and Taylor, D. 2014. Farmers' perceptions and actions to decrease crop raiding by forest-dwelling primates around a Rwandan forest fragment. Human Dimensions Wildlife, 19(2): 179-190.

Ogra, M.V. 2008. Human-wildlife conflict and gender in protected area borderlands: a case study of costs, perceptions, and vulnerabilities from Uttarakhand (Uttaranchal), India. Geoforum, 39(3): 1408-1422.

Quy, R.J., Massei, G., Lambert, M.S., Coats, J., Miller, L.A. and Cowan, D.P. 2014. Effects of a GnRH vaccine on the 
movement and activity of free-living wild boar (Sus scrofa). Wildlife Res., 41(3): 185-193.

Sabarathnam, V.E. 1987. A Study on the process of development and dissemination of dry land agricultural technology (Identification,
Unpublished Ph.D thesis. Acharya N. G. Ranga Agricultural University, Rajendranagar, Hyderabad - 30.

Thompson, S.C.G., and Barton, M.A. 1994. Ecocentric and anthropocentric attitudes toward the environment. J. Environ. Psychol., 14(2): 149-157.

\section{How to cite this article:}

Senthilkumar, K., P. Mathialagan, V.E. Sabarathnam and Manivannan, C. 2017. Development of Perception Test for Human-Wildlife Conflict. Int.J.Curr.Microbiol.App.Sci. 6(6): 817-824. doi: https://doi.org/10.20546/ijcmas.2017.606.096 